\title{
Synthesis, Identification and Evaluation the Biological Activity for Some New Heterocyclic Compounds Derived from Schiff Bases
}

\author{
Khitam T. A. Al-Sultani \\ (Department of Chemistry, College of Science/ Baghdad University, Iraq)
}

\begin{abstract}
This research involves synthesis some of new tetrazole, imidazolinone, thiazolidinone, and oxazepine derivatives. The first step includes formation Schiff bases (1-5) from condensation N-[(4-aminophenyl) carbamothioyl] benzamide with different aromatic aldehydein the presence of glacial acetic acid in DMF as a solvent. Four route with different reagents used for the cyclization of the prepared Schiff bases by reagent (sodium azide, 2-amino acetic acid, 2-mercapto acetic acid and phthalic anhydride) to form tetrazole (6-10), imidazolinone (11-15), Thiazolidinone (16-20), oxazepine(21-25) derivatives respectively. The structure of newly synthesized compounds were identified by spectral methods their [FTIR, and some of them by IHNMR, 13C-NMR] and measurements some of its physical properties and some specific reactions. The chemical structures of synthesized compounds were well characterized by 1HNMR, 13CNMR, FT-IR and TLC. Also, the effects of prepared compounds in some of strains of bacteria were studied.
\end{abstract}

Keywords: Schiff Bases, Tetrazole, Imidazolinone, Thiazolidinone, Oxazepine, Antibacterial.

\section{Introduction}

Schiff bases are chemical compounds possess general group $(-\mathrm{HC}=\mathrm{N}-)$ called azomethine. These compounds can be formed by react the primary amines with aldehydes or ketones in presence either acid, base or heat as a catalyst of the reaction [1]. Great deals of research have reported that Schiff bases which are derived from the heterocyclic compounds are antimicrobial [2], antiproliferative [3], anticonvulsant [4], cytotoxic [5] and anticancer [6]. Like the other organic compounds, schiff bases which consist of four, five and seven membered rings have biological activities based on its spectrum therefore many of industrial and medical applications like pigments and dyes take place in these fields [7-9]. Not only schiff bases are important, but their derivatives considered as one of the compounds which occupies the medical markets. For examples, oxoimidazoline which is also known imidazolinones, this substance has five membered rings with nitrogen atoms in 1 and positions exhibited many of biological activities such as CNS depressant, hypnotic and sedative $[10,11]$. Also, thiazolidine derivatives like 4-Thiazolidinones, this substance is formed by attacking the sulphur atom of imine group. This reaction contains cyclisation process to formed product of the schiff bases [12]. By using advanced analysis techniques combine with $\mathrm{CHN}$ analysis in order to characterize oxazepine compounds which are used commonly in colorectal cancer which consider as the most cancer type can be diagnosed which occurring because of many reasons like life style or increasing of age of human. The oxazepine can be synthesized by react the schiff bases with malic anhydride [13]. Finally, this paper aims to synthesis and characterize some new tetrazole, imidazolinone, thiazolidinone and oxazepine derivatives.

\subsection{Materials and Instruments}

\section{Experimental Part}

Chemicals supplied from Merck, BDH, Sigma Aldrich and Fluka companies and are used without further purification. Melting points were recorded using digital Stuart scientific SMP3 melting point apparatus and are uncorrected. FTIR spectra were recorded on SHIMAZU FTIR-8400 using KBr discs in the (4000-600) $\mathrm{cm}-1$ spectral range. 1HNMR and 13CNMR were recorded on Burker 500MHzistrument using $\mathrm{CDCl}_{3}-\mathrm{d}$ as solvent and TMS as internal reference. Thin layer chromatography (TLC) was carried out using Fertigfollenpre coated sheets type polygram silica and the plates were developed with iodine vapor.

\subsection{Methods}

2.2.1 Preparation of $\mathrm{N}$-[(4-aminophenyl) carbamothioyl] benzamide

This compound was prepared according to literature procedure [14].

2.2.2 Preparation of (E)-N-[4-(4-substitutedbenzylideneamino) phenylcarbamothioyl] benzamide (1-5)[15] Schiff bases have been synthesized by reaction of $\mathrm{N}$-[(4-aminophenyl) carbamothioyl] benzamide $(0.01$ mol, $0.5 \mathrm{gm}$.) with different substituted aromatic aldehyde (0.01 mol.) in DMF for (3-6 hour) in presence of (23 drops) of glacial acetic acid. The formed precipitate was filtered and recrystallized by ethanol. Physical properties of dry product and FTIR spectral data are listed in Table (1). 
Synthesis, Identification and Evaluation the Biological Activity for Some New Heterocyclic ..

Table 1 - Physical properties and FTIR spectral data $\mathrm{cm}^{-1}$ for the compounds (1-5).

\begin{tabular}{|c|c|c|c|c|c|c|c|c|c|c|}
\hline \multirow{2}{*}{$\begin{array}{l}\text { Com } \\
\text { p.No. }\end{array}$} & \multicolumn{4}{|c|}{ Physical Properties } & \multicolumn{6}{|c|}{ Major FTIR Absorption $\mathrm{cm}^{-1}$} \\
\hline & Structures & M.P. C & $\begin{array}{c}\text { Yield } \\
\%\end{array}$ & Color & $v \mathrm{~N}-\mathrm{H}$ & $\begin{array}{l}\mathrm{vC}-\mathrm{H} \\
\text { arom. }\end{array}$ & $v \mathrm{C}=\mathrm{N}$ & $v \mathrm{C}=\mathrm{S}$ & $v \mathbf{C}=\mathbf{O}$ & Other bands \\
\hline 1 & & 197-199 & 85 & Gray & 3180 & 3047 & 1650 & 1255 & 1649 & $\begin{array}{c}\text { vC-Cl } 1091 \\
\text { vp-position } \\
825\end{array}$ \\
\hline 2 & & $172-174$ & 90 & yellow & 3280 & 3029 & 1647 & 1255 & 1670 & $\begin{array}{c}\mathrm{NO}_{2} \\
\text { Asym.1515 } \\
\text { sym. } 1340 \\
\text { vpara- } \\
\text { position } 837\end{array}$ \\
\hline 3 & & 212-214 & 88 & $\begin{array}{c}\text { pale } \\
\text { yellow }\end{array}$ & 3185 & 3050 & 1668 & 1259 & 1649 & $\begin{array}{l}v \mathrm{v} \equiv \mathrm{N} \\
2223\end{array}$ \\
\hline 4 & & $110-112$ & 70 & brown & 3290 & 3031 & 1649 & 1259 & 1670 & $\begin{array}{c}\text { vC-Br } 970 \\
\text { vp-position } \\
827\end{array}$ \\
\hline 5 & & $222-224$ & 83 & $\begin{array}{c}\text { Off- } \\
\text { white }\end{array}$ & 3232 & 3051 & 1650 & 1253 & 1670 & $\begin{array}{c}\text { vC-O-C } \\
1107\end{array}$ \\
\hline
\end{tabular}

\subsubsection{Preparation of N-[4-(5-(4-substitutedphenyl)-1H-tetrazol-1-yl) phenylcarbamothioyl] benzamide (6-} 10)[16]

In order to stirring solution of Schiff-bases (1-5) $(0.003 \mathrm{~mol})$ in $(10 \mathrm{ml})$ of tetrahydrofuran, sodium azide $(0.003$ mol., $0.195 \mathrm{~g})$ in $10 \mathrm{ml}$ of tetrahydrofuran was added. The mixture was refluxed for $(10-14$ hours $)$, the end of reaction was checked by TLC which showed the disappearance of the starting materials, then cooled the mixture at room temperature and the precipitate was filtered, washed with cold water, recrystallized with ethanol. Physical properties of dry product and FTIR spectral data are listed in Table (2).

Table 2 - Physical properties and FTIR spectral data $\mathrm{cm}^{-1}$ for the compounds (6-10).

\begin{tabular}{|c|c|c|c|c|c|c|c|c|c|c|}
\hline \multirow{2}{*}{$\begin{array}{l}\text { Comp. } \\
\text { No. }\end{array}$} & \multicolumn{4}{|c|}{ Physical Properties } & \multicolumn{6}{|c|}{ Major FTIR Absorption $\mathrm{cm}^{-1}$} \\
\hline & Structures & M.P.C & $\begin{array}{c}\text { Yield } \\
\% \\
\end{array}$ & Color & $\mathrm{vN}-\mathrm{H}$ & $\begin{array}{l}v \mathrm{C}-\mathrm{H} \\
\text { arom. }\end{array}$ & $v C=0$ & ${ } \mathrm{C}=\mathrm{S}$ & $v C=N$ & Other bands \\
\hline 6 & & 207-209 & 75 & $\begin{array}{c}\text { Pale- } \\
\text { yellow }\end{array}$ & 3180 & 3047 & 1649 & 1255 & 1600 & $\begin{array}{c}v(\mathrm{~N}=\mathrm{N}) 1523 \\
v(\mathrm{C}-\mathrm{Cl}) 1080 \\
v p-\text { position } 835\end{array}$ \\
\hline 7 & & $210-212$ & 72 & yellow & 3192 & 3029 & 1670 & 1255 & 1600 & $\begin{array}{c}v(\mathrm{~N}=\mathrm{N}) 1515 \\
v \mathrm{NO} 2 \\
\text { Asym. } 1515 \\
\text { Sym. } 1342\end{array}$ \\
\hline 8 & & $220-221$ & 80 & Green & 3185 & 3050 & 1649 & 1259 & 1603 & $\begin{array}{c}v(\mathrm{~N}=\mathrm{N}) 1514 \\
v \mathrm{C} \equiv \mathrm{N} 2223\end{array}$ \\
\hline 9 & & $\begin{array}{c}133 \\
\text { decomp. }\end{array}$ & 65 & $\begin{array}{l}\text { Light } \\
\text { brown }\end{array}$ & 3290 & 3031 & 1670 & 1259 & 1616 & $\begin{array}{c}v(\mathrm{~N}=\mathrm{N}) 1521 \\
v \mathrm{C}-\mathrm{Br} 889 \\
\mathrm{vp}-\mathrm{position} 835\end{array}$ \\
\hline 10 & & $\begin{array}{c}263 \\
\text { decomp. }\end{array}$ & 60 & white & 3232 & 3051 & 1650 & 1253 & 1602 & $\begin{array}{l}v(\mathrm{~N}=\mathrm{N}) 1515, \\
v(\mathrm{C}-\mathrm{O}-\mathrm{C}) 1147\end{array}$ \\
\hline
\end{tabular}

\subsubsection{Preparation of N-[4-(2-(4-chlorophenyl)-5-oxoimidazolidin-1-yl)phenylcarbamothioyl]benzamide(11-} 15) $[10]$

A solution of appropriate Schiff bases (1-5) (0.0013 mol.) in (15 ml) of tetrahydrofuran as solvent and 2-aminoacetic acid $(0.097 \mathrm{~g} ., 0.0013 \mathrm{~mol}$.) in $(5 \mathrm{ml}$.) of tetrahydrofuran was refluxed for (16-20hours), then the reaction mixture was cooled at room temperature and the precipitate was filtered, washed with coldwater and recrystallized by ethanol. Physical properties of dry product and FTIR spectral data are listed in Table (3). 
Synthesis, Identification and Evaluation the Biological Activity for Some New Heterocyclic ..

Table 3 - physical properties and FTIR spectral data $\mathrm{cm}^{-1}$ for the compounds (11-15).

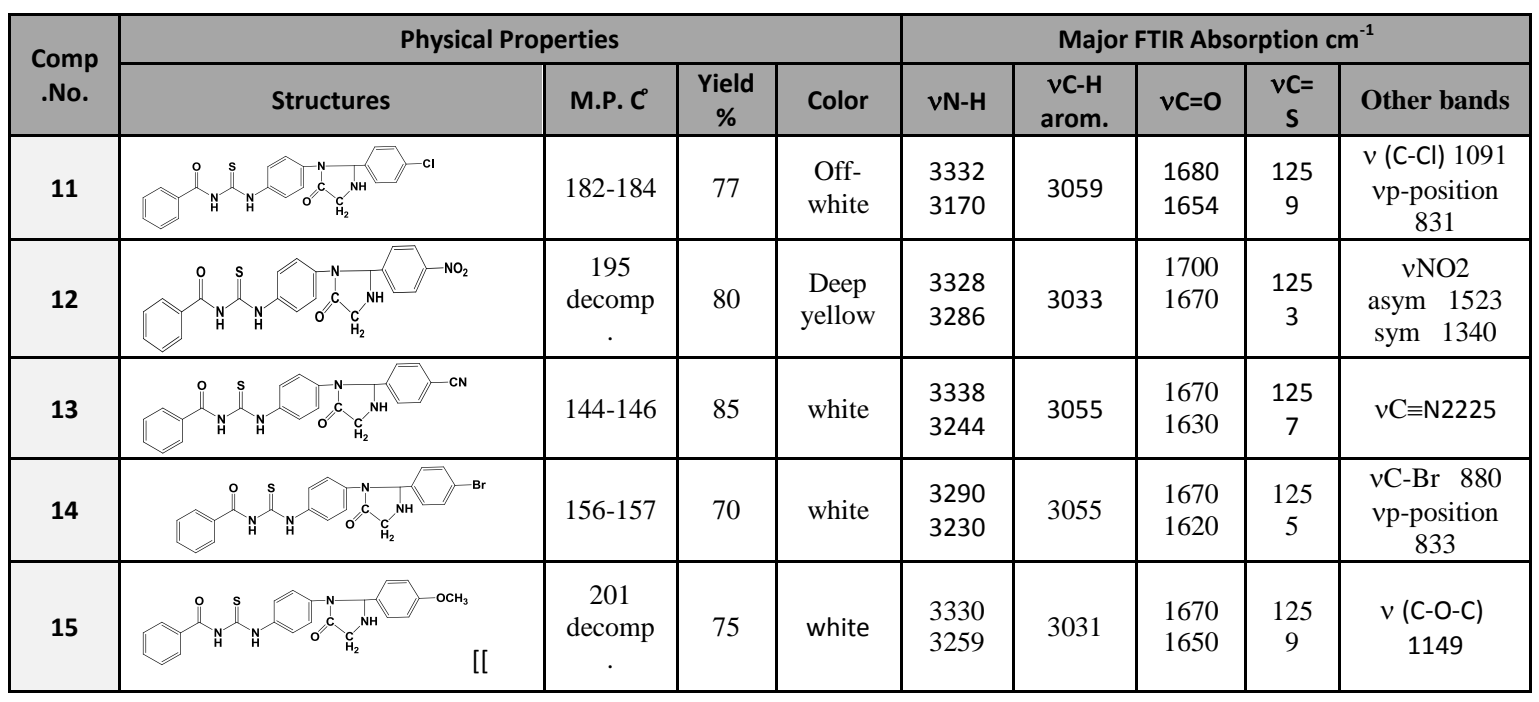

\subsubsection{Preparation of N-[(4-(2-(4-substitutedphenyl)-4-oxothiazolidin-3-yl) phenyl)carbamothioyl]} benzamide(16-20) [16]

A mixture of Schiff-bases (1-5) $(0.003 \mathrm{~mol})$ in tetrahydrofuran (15ml) and mercaptoacetic acid $(0.003 \mathrm{~mol}, 0.2 \mathrm{ml})$ in tetrahydrofuran with a pinch of anhydrous zinc chloride was refluxed on water bath (14-16 hours). The separated solid was filtered, dried and crystallized by ethanol. Physical properties of dry product and FTIR spectral data are listed in Table (4).

Table 4- physical properties and FTIR spectral data cm-1for the compounds (16-20).

\begin{tabular}{|c|c|c|c|c|c|c|c|c|c|}
\hline \multirow[b]{2}{*}{$\begin{array}{c}\text { Comp. } \\
\text { No. }\end{array}$} & \multicolumn{4}{|c|}{ Physical Properties } & \multicolumn{5}{|c|}{ Major FTIR Absorption $\mathrm{cm}^{-1}$} \\
\hline & Structures & M.P. C & $\begin{array}{c}\text { Yield } \\
\%\end{array}$ & Color & $\mathrm{vN}-\mathrm{H}$ & $\begin{array}{l}\mathrm{VC}-\mathrm{H} \\
\text { arom. }\end{array}$ & $v C=0$ & $v C=S$ & $\begin{array}{l}\text { Other } \\
\text { bands }\end{array}$ \\
\hline 16 & & $\begin{array}{l}193- \\
195\end{array}$ & 78 & white & 3145 & 3051 & 1679 & 1257 & $\begin{array}{c}v(\mathrm{C}- \\
\mathrm{Cl}) 1091 \\
\text { vp-position } \\
829\end{array}$ \\
\hline 17 & & $\begin{array}{l}209- \\
211\end{array}$ & 88 & $\begin{array}{l}\text { Dark- } \\
\text { yellow }\end{array}$ & 3190 & 3035 & 1670 & 1255 & 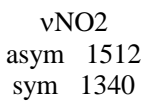 \\
\hline 18 & & $\begin{array}{l}218- \\
220\end{array}$ & 85 & $\begin{array}{l}\text { Off- } \\
\text { white }\end{array}$ & 3185 & 3012 & 1670 & 1255 & $\begin{array}{l}v C \equiv N \\
2223\end{array}$ \\
\hline 19 & & $\begin{array}{c}177- \\
179\end{array}$ & 77 & Brown & 3220 & 3031 & 1672 & 1257 & $\begin{array}{c}v C-B r \quad 896 \\
\text { vp-position } \\
835\end{array}$ \\
\hline 20 & & $\begin{array}{c}221 \\
\text { decom } \\
\text { p. }\end{array}$ & 65 & white & 3232 & 3022 & 1653 & 1259 & $\begin{array}{c}v(\mathrm{C}-\mathrm{O}-\mathrm{C}) \\
1151\end{array}$ \\
\hline
\end{tabular}

\subsubsection{Preparation of N-[(4-(3-(4-chlorophenyl)-1,5-dioxobenzo[e][1,3]oxazepin-4(1H,3H,5H)-} yl)phenyl)carbamothioyl]benzamide(21-25)[17]

A mixture of Schiff base (1-5) (0.001mole) and phthalic anhydride (0.001mole) was dissolved in $(20 \mathrm{~mL})$ in tetrahydrofuran. The mixture was heated for 7 hours in water bath at $\left(70^{\circ} \mathrm{C}\right)$, excess solvent was distilled, and the precipitate was filtered and recrystallized by ethanol. Physical properties of dry product and FTIR spectral data are listed in Table (5). 
Synthesis, Identification and Evaluation the Biological Activity for Some New Heterocyclic ..

Table 5 - Physical properties and FTIR spectral data cm-1for the compounds (21-25).

\begin{tabular}{|c|c|c|c|c|c|c|c|c|c|}
\hline \multirow{2}{*}{$\begin{array}{c}\text { Comp. } \\
\text { No. }\end{array}$} & \multicolumn{4}{|c|}{ Physical Properties } & \multicolumn{5}{|c|}{ Major FTIR Absorption $\mathrm{cm}^{-1}$} \\
\hline & Structures & $\begin{array}{c}\text { M.P. } \\
\text { C }\end{array}$ & $\begin{array}{c}\text { Yield } \\
\%\end{array}$ & Color & vN-H & $\begin{array}{l}\mathrm{VC}-\mathrm{H} \\
\text { arom. }\end{array}$ & $v C=0$ & $v C=S$ & Other bands \\
\hline 21 & & $\begin{array}{c}132- \\
134\end{array}$ & 65 & white & 3190 & 3034 & 1672 & 1257 & $\begin{array}{c}v(\mathrm{C}=\mathrm{O}) \\
\text { phthalic } \\
1770 \\
v(\mathrm{C}-\mathrm{Cl}) 1089 \\
\text { vp-position } \\
837 \\
\end{array}$ \\
\hline 22 & & $\begin{array}{l}215- \\
217\end{array}$ & 80 & $\begin{array}{l}\text { Pale } \\
\text { yellow }\end{array}$ & 3188 & 3040 & 1668 & 1255 & $\begin{array}{c}v(\mathrm{C}=\mathrm{O}) \\
\text { phthalic } \\
1779 \\
v \mathrm{NO} 2 \\
\text { asym } 1523 \\
\text { sym } \quad 1336 \\
\end{array}$ \\
\hline 23 & & $\begin{array}{l}223- \\
225\end{array}$ & 66 & Gray & 3185 & 3033 & 1670 & 1255 & $\begin{array}{c}v(C=0) \\
\text { phthalic } \\
1770 \\
v C \equiv N \\
2200\end{array}$ \\
\hline 24 & [ & $\begin{array}{c}148- \\
150\end{array}$ & 60 & Brown & 3280 & 3031 & 1673 & 1250 & $\begin{array}{c}v(\mathrm{C}=\mathrm{O}) \\
\text { phthalic } \\
1760 \\
v \mathrm{C}-\mathrm{Br} 880 \\
\text { vp-position } \\
825\end{array}$ \\
\hline 25 & & $\begin{array}{c}170- \\
172\end{array}$ & 75 & white & 3210 & 3033 & 1660 & 1258 & $\begin{array}{c}v(\mathrm{C}=\mathrm{O}) \\
\text { phthalic } \\
1760 \\
v(\mathrm{C}-\mathrm{O}-\mathrm{C}) \\
1142 \\
\end{array}$ \\
\hline
\end{tabular}

\subsection{Anti-microbial activity test [18]}

The test was performed according to the disk diffusion method. Some of prepared compounds were tested against two strain gram +ve (Staphylococcus aura and Bacillus) and two strain gram -ve bacteria (pseudomonas and Escherichia coli). Filter paper (Whattman no.1) disk of $5 \mathrm{~mm}$ diameter were sterilized by

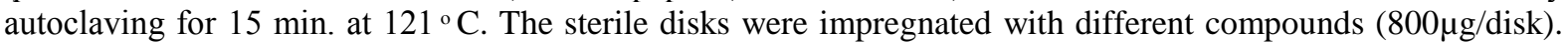
Agar plates were surface inoculated uniformly with $100 \mu \mathrm{L}$ from both culture of tested microorganism. The impregnated disk were placed on the medium suitably spaced a part and the plates incubated at $5^{\circ} \mathrm{C}$ for 1 hour. to permit good diffusion and then transferred to an incubator at $37^{\circ} \mathrm{C}$ for 24 hours. The inhibition zones caused by various compounds on the microorganisms were examined.

\section{Results And Discussion}

The synthetic sequences for preparation of new series of Tetrazole, Thiazolidinone, Imidazolinone and Oxazepine all these derivatives as shown in scheme (1).

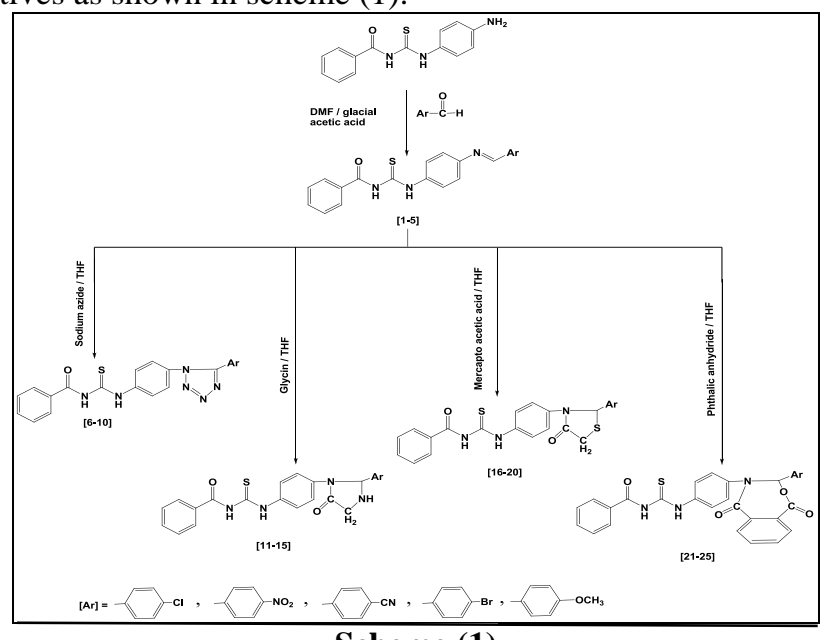

Scheme (1) 
Schiff bases (1-5) were prepared by reaction of compound N-[(4-aminophenyl) carbamothioyl] benzamide with different aromatic aldehydes in presence of glacial acetic acid ,the structure for these compounds were confirmed by physical properties listed in Table(1). FTIR spectrum showed disappearance of absorption band for $\mathrm{NH}_{2}$ group and appearance of the absorption band at $(1668-1647) \mathrm{cm}^{-1}$ to $(\mathrm{C}=\mathrm{N})$ [19] and show other different absorption bands for the substituted groups that are listed in Table (1). ${ }^{1}$ HNMR spectrum for compound (2) show signals at v 7.30-8.42 ppm; v8.65 ppm (s, $1 \mathrm{H},-\mathrm{N}=\mathrm{CH}-$ ); v $9.16 \mathrm{ppm}$ (s, 1H, -CS-N $\underline{\mathrm{H}}-\mathrm{Ph}$ ); $(\mathrm{m}, 13 \mathrm{H}, \mathrm{Ar}-\underline{\mathrm{H}})$ and $v 10.30 \mathrm{ppm}(\mathrm{s}, 1 \mathrm{H},-\mathrm{CO}-\mathrm{N} \underline{\mathrm{H}}-\mathrm{CS}-)$ [20 figure (1). ${ }^{13} \mathrm{CNMR}$ spectrum for this compound show signals listed in Table (7) and figure (2). Schiff bases were cyclized by using four different steps with different reagents.

First step include treatment schiff bases with sodium azide to give tetrazole derivatives (6-10), the synthetic steps are shown in scheme (1). The mechanism of the reaction systematically investigated as [3+2] cyclo additions which christened as a 1,3-dipolar cyclo additions. Involved the addition of unsaturated systems to 1,3-dipoles, a molecule possessing resonance contributors in which positive and negative charges are located in 1,3-position relative to each other. The addition results five membered rings. Physical properties of compounds (6-10) are listed in Table (2). FTIR spectra of compounds (6-10) showed bands at (1523-1514) $\mathrm{cm}^{-1}$ are due to the cyclic $(\mathrm{N}=\mathrm{N})$ stretching of tetrazole ring. Also, the FTIR for these compounds show the other absorptions bands at $(3290-3180) \mathrm{cm}^{-1},(1670-1649) \mathrm{cm}^{-1}$, (1616-1600) $\mathrm{cm}^{-1}$, and (1259-1253) $\mathrm{cm}^{-1}$, due to $v(\mathrm{NH}), v(\mathrm{C}=\mathrm{O}), v(\mathrm{C}=\mathrm{N})$ and $v(\mathrm{C}=\mathrm{S})$ respectively, the other substituted groups are listed in Table (2). ${ }^{1} \mathrm{HNMR}$ spectral data of compounds (7 and 8) shows disappearance of the proton of azomethene group, the results listed in Table (6), figure (3) for compound (7) and ${ }^{13} \mathrm{CNMR}$ spectral data of compounds (7 and 8) show results listed in Table (7), figure (4) for compound (7).

The second step of cyclization of Schiff bases was achieved by using 2-aminoaceticacid in tetrahydrofuran to give imdazolidone derivatives (11-15).FTIR spectra of compounds (1115)showeddisappearance of absorption band at $(1668-1647) \mathrm{cm}^{-1}$ for $v(\mathrm{C}=\mathrm{N})$ and appearance of absorption bands at $(3338-3170) \mathrm{cm}^{-1}$ and $(1670-1620) \mathrm{cm}^{-1}$ and $v(C=O)$ band of imidazolidone ring respectively. All details of FTIR spectral data of compounds (11-15) are listed in Table(3). ${ }^{1}$ HNMR spectral data of compound (11) show the disappearance of signal proton of azomethene group $(-\mathrm{N}=\mathrm{C} \underline{H}-)$ and appearance of new signals for the imidazolidone ring that are listed in Table (6) and ${ }^{13}$ CNMR spectral data are listed in Table (7).

The third cyclization step of Schiff bases with 2-mercapto acetic acid in THF to give thiazolidinone derivatives (15-20). FTIR spectra of compounds (15-20) showed disappearance of absorption bands at (16681647) $\mathrm{cm}^{-1}$ for $v(\mathrm{C}=\mathrm{N})$ and appearance of absorption band at $(1679-1653) \mathrm{cm}^{-1}$ due to $v(\mathrm{C}=\mathrm{O})$ of thiazolidinonerings. All details of FTIR spectral data of compounds (15-20) are listed in Table(4). ${ }^{1} \mathrm{HNMR}$ spectral data of compound $(16,18)$ show disappearance signals proton of azomethane group $(-\mathrm{N}=\mathrm{C} \underline{H}-)$ and appearance new signals for the thiazolidinone rings listed in Table (6) and ${ }^{13} \mathrm{CNMRspectral}$ data listed in Table (7).

The last cyclization step of Schiff bases with phthalic anhydride to result seven membered rings by cyclo addition reaction is classified as a [5+2] implying 5-atome component plus 2 -atom component leading to 7-membered cyclic ring. Physical properties of oxazepin derivatives (21-25) are listed in Table (5). FTIR spectra of compounds (21-25) showed bands at $(1779-1760) \mathrm{cm}^{-1}$ due to the cyclic $(\mathrm{C}=\mathrm{O})$ stretching of ketone imide ring, the other substituted groups are listed in Table (5). ${ }^{1} \mathrm{HNMR}$ spectral data of compounds (21 and 22) shows disappearance of proton of azomethane group and appearance signal for proton oxazepin ring, the results listed in Table (6) and ${ }^{13} \mathrm{CNMRspectral} \mathrm{data} \mathrm{of} \mathrm{compounds} \mathrm{(21} \mathrm{and} \mathrm{22)} \mathrm{show} \mathrm{results} \mathrm{listed} \mathrm{in} \mathrm{Table} \mathrm{(7).}$

Table 6: $1 \mathrm{H}-\mathrm{NMR}$ spectral data $(\delta \mathrm{ppm})$ for the selected compounds

\begin{tabular}{|c|c|c|}
\hline $\begin{array}{l}\text { Comp. } \\
\text { No. }\end{array}$ & Structures & ${ }^{1}$ HNMR Spectral data( $\delta$ ppm $)$ \\
\hline 2 & & $\begin{array}{l}7.30-8.42(\mathrm{~m}, 13 \mathrm{H}, \mathrm{Ar}-\underline{\mathrm{H}}) ; 8.65(\mathrm{~s}, 1 \mathrm{H},-\mathrm{N}=\mathrm{CH}-) ; 9.16(\mathrm{~s}, 1 \mathrm{H},-\mathrm{CS}- \\
\mathrm{N} \underline{\mathrm{H}}-\mathrm{Ph}) ; 10.30(\mathrm{~s}, 1 \mathrm{H},-\mathrm{CO}-\mathrm{N} \underline{\mathrm{H}}-\mathrm{CS}-)\end{array}$ \\
\hline 7 & & $\begin{array}{l}7.355-8.375(\mathrm{~m}, 13 \mathrm{H}, \mathrm{Ar}-\underline{\mathrm{H}}) ; 9.15(\mathrm{~s}, 1 \mathrm{H},-\mathrm{CS}-\mathrm{N} \underline{\mathrm{H}}-\mathrm{Ph}) ; 10.20(\mathrm{~s}, \\
1 \mathrm{H},-\mathrm{CO}-\mathrm{N} \underline{\mathrm{H}}-\mathrm{CS}-)\end{array}$ \\
\hline 8 & & $\begin{array}{l}7.30-8.20(\mathrm{~m}, 13 \mathrm{H}, \mathrm{Ar}-\underline{\mathrm{H}}) ; 9.20(\mathrm{~s}, 1 \mathrm{H},-\mathrm{CS}-\mathrm{N} \underline{\mathrm{H}}-\mathrm{Ph}) ; 10.28(\mathrm{~s}, \\
1 \mathrm{H},-\mathrm{CO}-\mathrm{N} \underline{\mathrm{H}}-\mathrm{CS}-)\end{array}$ \\
\hline 11 & & $\begin{array}{l}3.20\left(\mathrm{~s}, 1 \mathrm{H},-\mathrm{CH}_{2}-\mathrm{NH}-\mathrm{CH}-\right) ; 5.33\left(\mathrm{~s}, 2 \mathrm{H},-\mathrm{CH}_{2}-\mathrm{NH}-\mathrm{CH}-\right) ; 7.47- \\
7.91(\mathrm{~m}, 13 \mathrm{H}, \mathrm{Ar}-\underline{\mathrm{H}}) ; 9.28(\mathrm{~s}, 1 \mathrm{H},-\mathrm{CS}-\mathrm{N} \underline{\mathrm{H}}-\mathrm{Ph}) ; 10.15(\mathrm{~s}, 2 \mathrm{H},- \\
\left.\mathrm{CH}_{2}-\mathrm{N} \underline{\mathrm{H}}-\mathrm{CH}-\text { overlap with -CO-N } \underline{\mathrm{H}}-\mathrm{CS}-\right)\end{array}$ \\
\hline
\end{tabular}


Synthesis, Identification and Evaluation the Biological Activity for Some New Heterocyclic ..

\begin{tabular}{|c|c|}
\hline 16 & 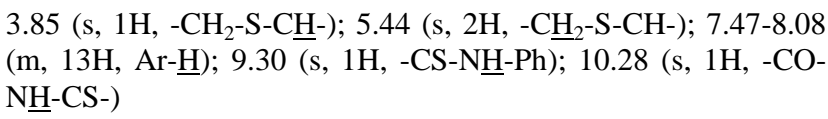 \\
\hline 18 & $\begin{array}{l}3.82\left(\mathrm{~s}, 1 \mathrm{H},-\mathrm{CH}_{2}-\mathrm{S}-\mathrm{CH}-\right) ; 5.42\left(\mathrm{~s}, 2 \mathrm{H},-\mathrm{CH}_{2}-\mathrm{S}-\mathrm{CH}-\right) ; 7.53-7.95 \\
(\mathrm{~m}, 13 \mathrm{H}, \mathrm{Ar}-\underline{\mathrm{H}}) ; 9.21(\mathrm{~s}, 1 \mathrm{H},-\mathrm{CS}-\mathrm{N} \underline{\mathrm{H}}-\mathrm{Ph}) ; 10.30(\mathrm{~s}, 1 \mathrm{H},-\mathrm{CO}- \\
\mathrm{N} \underline{\mathrm{H}}-\mathrm{CS}-)\end{array}$ \\
\hline 21 & $\begin{array}{l}7.10(\mathrm{~s}, 1 \mathrm{H},-\mathrm{CO}-\mathrm{O}-\mathrm{C} \underline{\mathrm{H}}-) ; 7.45-7.95(\mathrm{~m}, 17 \mathrm{H}, \mathrm{Ar}-\underline{\mathrm{H}}) ; 9.25(\mathrm{~s}, 1 \mathrm{H}, \\
-\mathrm{CS}-\mathrm{N} \underline{\mathrm{H}}-\mathrm{Ph}) ; 10.50(\mathrm{~s}, 1 \mathrm{H},-\mathrm{CO}-\mathrm{N} \underline{\mathrm{H}}-\mathrm{CS}-)\end{array}$ \\
\hline 22 & $\begin{array}{l}7.12(\mathrm{~s}, 1 \mathrm{H},-\mathrm{CO}-\mathrm{O}-\mathrm{C} \underline{\mathrm{H}}-) ; 7.54-8.44(\mathrm{~m}, 17 \mathrm{H}, \mathrm{Ar}-\underline{\mathrm{H}}) ; 9.13(\mathrm{~s}, 1 \mathrm{H}, \\
-\mathrm{CS}-\mathrm{N} \underline{\mathrm{H}}-\mathrm{Ph}) ; 10.19(\mathrm{~s}, 1 \mathrm{H},-\mathrm{CO}-\mathrm{N} \underline{\mathrm{H}}-\mathrm{CS}-)\end{array}$ \\
\hline
\end{tabular}

Table 7: $13 \mathrm{CNMR}$ spectral data $(\delta \mathrm{ppm})$ for the selected compounds.

\begin{tabular}{|c|c|c|}
\hline $\begin{array}{l}\text { Comp. } \\
\text { No. }\end{array}$ & Compound structure & ${ }^{13} \mathrm{CNMR}$ spectral data $(\delta \mathrm{ppm})$ \\
\hline 2 & & $\begin{array}{l}120.33-135.92(\mathrm{C}-\text { aromatic rings }) ; 157.45(\mathrm{C}=\mathrm{N}) ; 166.99 \\
(\mathrm{C}=\mathrm{O}) ; 178.20(\mathrm{C}=\mathrm{S})\end{array}$ \\
\hline 7 & & $\begin{array}{l}120.34-149.39 \quad(\mathrm{C}-\text { aromatic rings }) ; 157.55 \quad(\mathrm{C}=\mathrm{N} \text { tetrazole }) \\
167.05(\mathrm{C}=\mathrm{O}) ; 178.31(\mathrm{C}=\mathrm{S})\end{array}$ \\
\hline 8 & & $\begin{array}{l}118.44(\mathrm{C} \equiv \mathrm{N}) ; 120.35-149.28(\mathrm{C}-\text { aromatic rings }) ; 160.95(\mathrm{C}=\mathrm{N} \\
\text { tetrazole }) ; 167.06(\mathrm{C}=\mathrm{O}) ; 178.33(\mathrm{C}=\mathrm{S})\end{array}$ \\
\hline 11 & & $\begin{array}{l}58.30\left(-\mathrm{CH}_{2}-\mathrm{NH}-\mathrm{CH}-\right) ; 77.24 \quad\left(-\mathrm{CH}_{2}-\mathrm{NH}-\mathrm{CH}-\right) ; 120.36-134.82 \\
(\mathrm{C}-\text { aromatic rings); } 168.00 \quad(\mathrm{C}=\mathrm{O} \text { amide); } 171.2 \quad(\mathrm{C}=\mathrm{O} \\
\text { imidazolin ring); } 178.40(\mathrm{C}=\mathrm{S})\end{array}$ \\
\hline 16 & & $\begin{array}{l}52.30\left(-\mathrm{CH}_{2}-\mathrm{S}-\mathrm{CH}-\right) ; 77.24\left(-\mathrm{CH}_{2}-\mathrm{S}-\mathrm{CH}-\right) ; 120.36-133.87\left(\mathrm{C}-{ }^{-}-1\right. \\
\text { aromatic rings }) ; 167.20(\mathrm{C}=\mathrm{O} \text { amide }) ; 171.00(\mathrm{C}=\mathrm{O} \text { thiazolidine } \\
\text { ring); } 179.00(\mathrm{C}=\mathrm{S})\end{array}$ \\
\hline 18 & & $\begin{array}{l}60.21\left(-\mathrm{CH}_{2}-\mathrm{S}-\mathrm{CH}-\right) ; 77.35\left(-\mathrm{CH}_{2}-\mathrm{S}-\mathrm{CH}-\right) ; 117.90 \quad(\mathrm{C} \equiv \mathrm{N}) \text {; } \\
121.20-135.80(\mathrm{C}-\text { aromatic rings }) ; 167.22-168.20(\mathrm{C}=\mathrm{O} \text { amide } \\
\text { with } \mathrm{C}=\mathrm{O} \text { thiazolidine ring); } 179.00(\mathrm{C}=\mathrm{S})\end{array}$ \\
\hline 21 & & $\begin{array}{l}\text { 120.36 (-CO-O-CH-); } 124.37-142.20(\mathrm{C}-\text { aromatic rings); } 167.20 \\
(\mathrm{C}=\mathrm{O} \text { amide); } 173.42(\mathrm{C}=\mathrm{O} \text { oxazepin ring }) ; 178.50(\mathrm{C}=\mathrm{S})\end{array}$ \\
\hline 22 & & $\begin{array}{l}120.40(-\mathrm{CO}-\mathrm{O}-\mathrm{C} \mathrm{H}-) ; 124.36-142.40(\mathrm{C}-\text { aromatic rings); } 167.70 \\
(\mathrm{C}=\mathrm{O} \text { amide }) ; 174.00(\mathrm{C}=\mathrm{O} \text { oxazepin ring }) ; 178.60(\mathrm{C}=\mathrm{S})\end{array}$ \\
\hline
\end{tabular}

\section{Anti-microbial activity:}

The results of antibacterial activity are listed in Table (8). The results referred that all synthetic compounds possess moderate activity against certain types of bacteria, while it did not possess any activity against others. Compounds ( 3 and 24 ) possess strong activity against Escherichia coli, while compounds (13 and 22) possess strong activity against Staphylococcus aureus. Compounds (3, 9, 13, and 24) showed weak activity against Bacillus. However, compounds $(5,8,11,17$, and 22) showed no inhibition for the same bacteria. As far as compounds ( 8 and 24) possess modest activity against Pseudomonas, while no inhibition activity was found for compounds $(3,11,13$, and 19). 
Synthesis, Identification and Evaluation the Biological Activity for Some New Heterocyclic ..

Table 8: Anti-microbial activity of some of the prepared compounds

\begin{tabular}{|c|c|c|c|c|}
\hline $\begin{array}{c}\text { Comp. } \\
\text { No. }\end{array}$ & $\begin{array}{c}\text { Staphylococcus } \\
\text { aureus+ve }\end{array}$ & Bacillus +ve & $\begin{array}{c}\text { Pseudomonas } \\
-\mathrm{ve}\end{array}$ & $\begin{array}{c}\text { Escherichia coli- } \\
\text { ve }\end{array}$ \\
\hline $\mathbf{3}$ & 8 & 3 & - & 11 \\
\hline $\mathbf{5}$ & 6 & - & 4 & 9 \\
\hline $\mathbf{8}$ & - & - & 10 & 6 \\
\hline $\mathbf{9}$ & 10 & 5 & 4 & 8 \\
\hline $\mathbf{1 1}$ & 9 & - & - & 10 \\
\hline $\mathbf{1 3}$ & 13 & 3 & - & 3 \\
\hline $\mathbf{1 7}$ & 4 & - & 9 & - \\
\hline $\mathbf{1 9}$ & 6 & 7 & - & 9 \\
\hline $\mathbf{2 2}$ & 12 & - & 3 & 12 \\
\hline $\mathbf{2 4}$ & 9 & 4 & 7 & \\
\hline
\end{tabular}

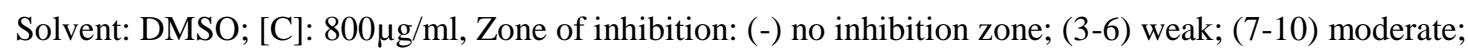
(11-15) strong.

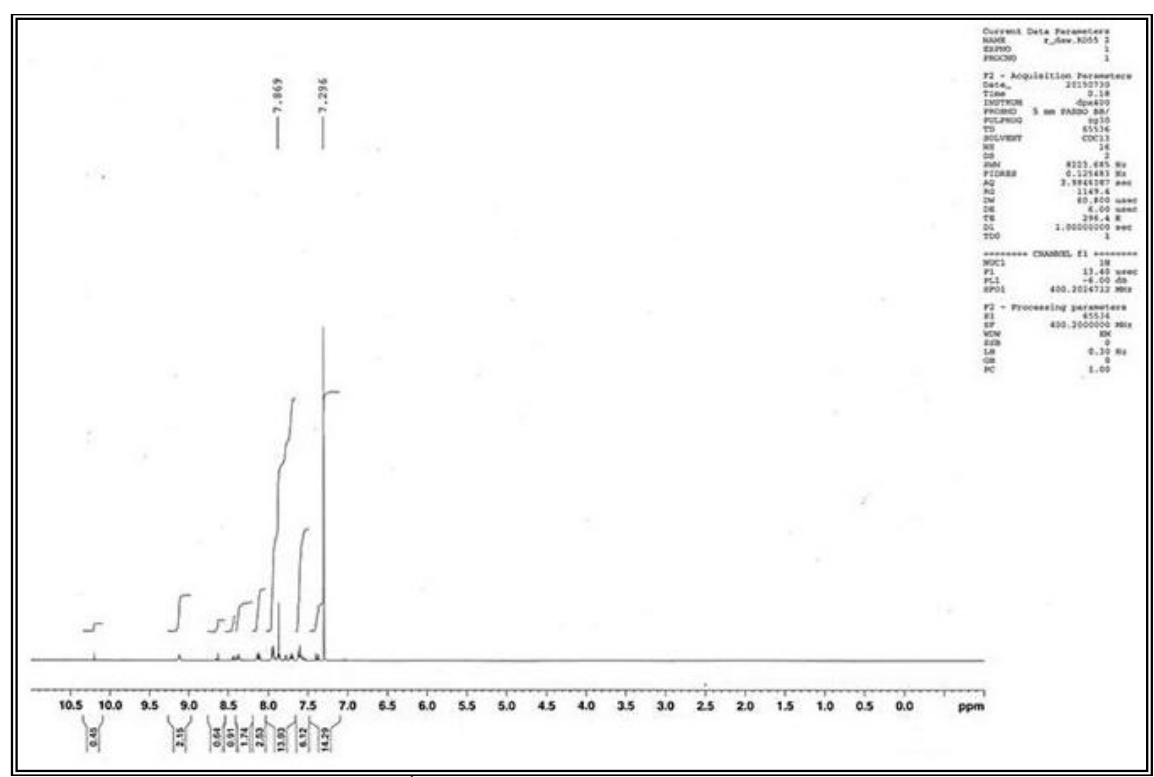

Figure (1): ${ }^{1}$ HNMR spectrum for compound (2).

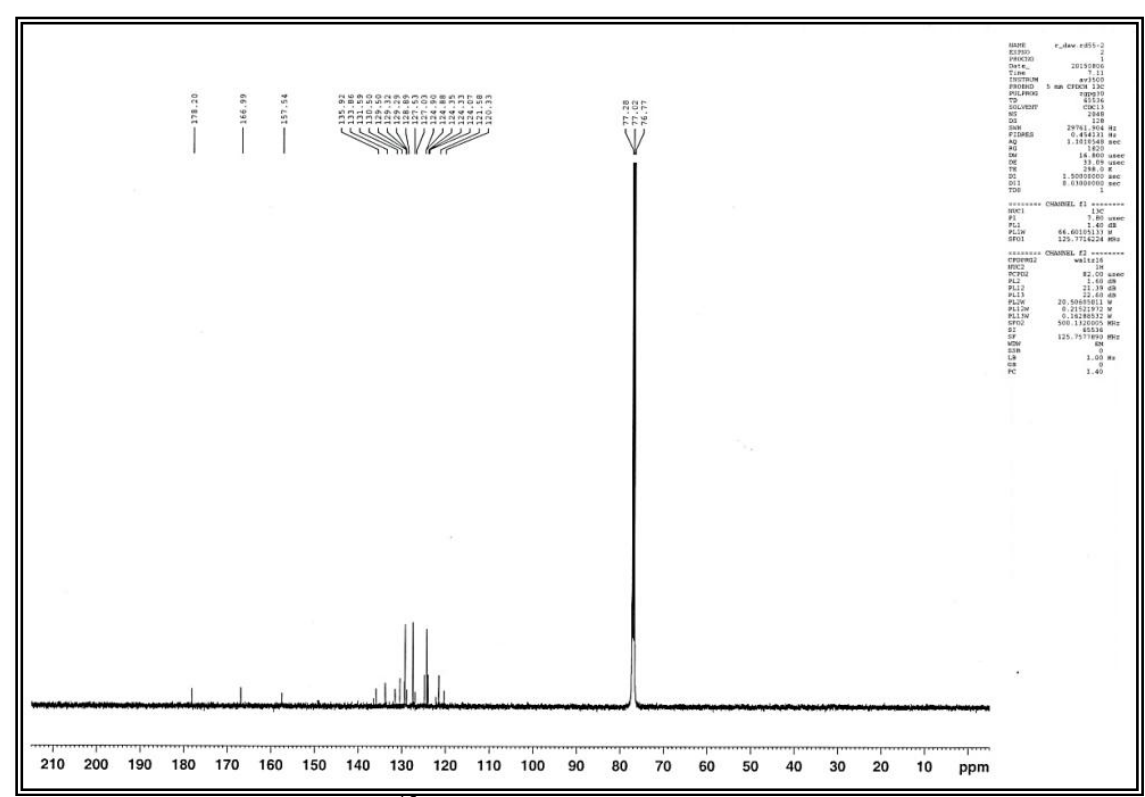

Figure (2): ${ }^{13}$ CNMR spectrum for compound (2). 


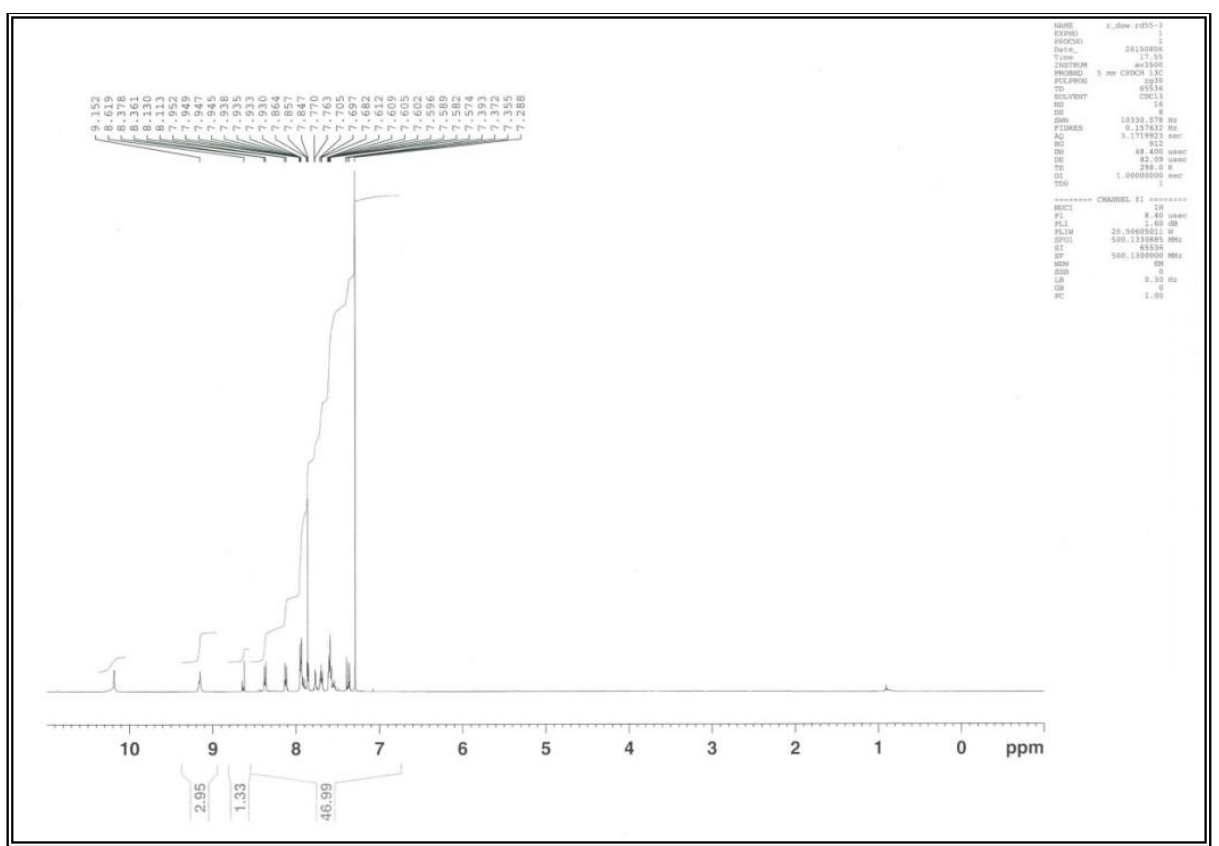

Figure (3): ${ }^{1}$ HNMR spectrum for compound (7).

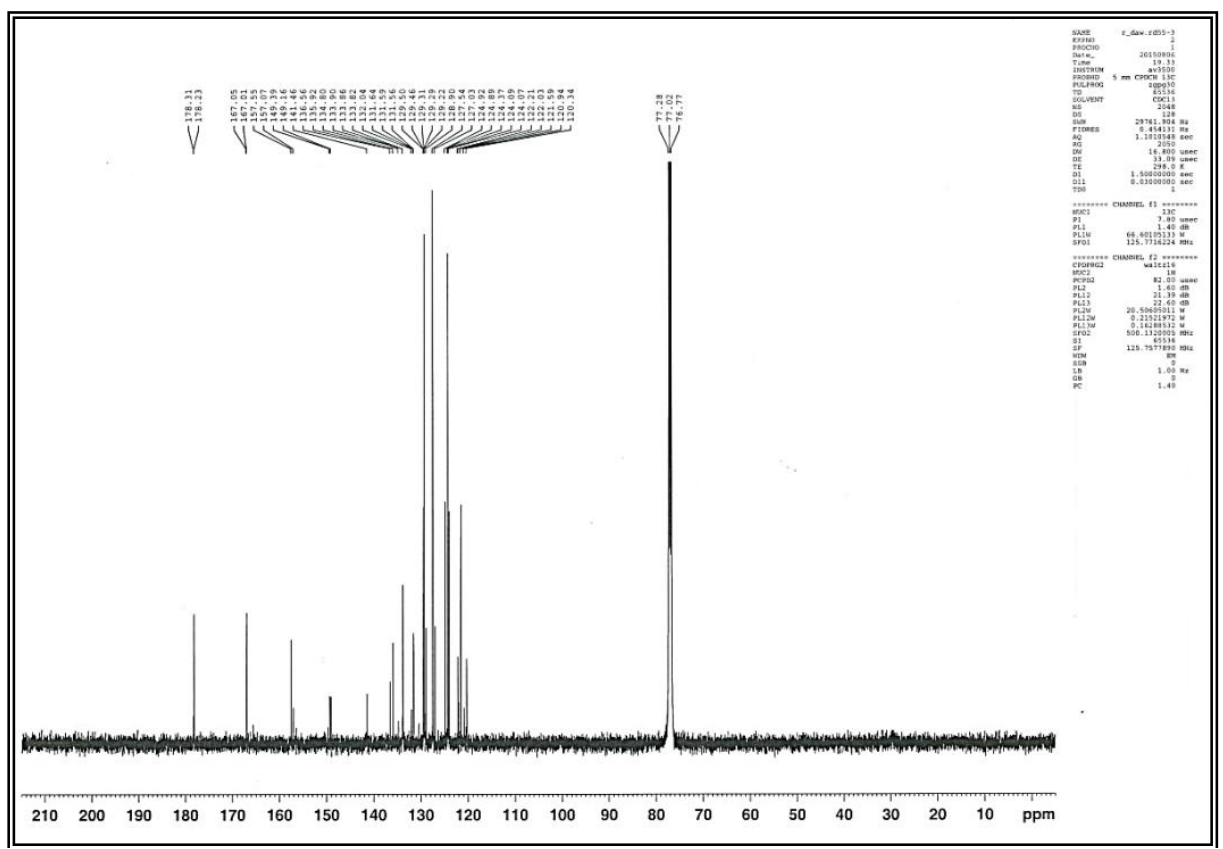

Figure (4):13CNMR spectrum for compound (7).

\section{References}

[1] ZahraaS. M., Ivan H. R. and Ali H. R., synthesis and characterization of new aminoacid-schiff bases and studies their effects on the activity of acp, pap and npa enzymes (in vitro), e-journal of chemistry, 9(2), 2012, 962-969.

[2] Kahveci B.,Bekircan O. and Karaoglu S., Synthesis and antimicrobial activity of some 3-alkyl-4-(arylmethyleneamino)-4,5dihydro-1H-1,2,4-triazol-5-ones,Indian J. Chem., 44B, 2005, 2614-2617.

[3] Vicini P.,GeronikakiA.,Incerti M.,Busonera B.,Poni G.,Kabras C.A.,Colla P.L., Synthesis and biological evaluation of benzo[d]isothiazole, benzothiazole and thiazole Schiff bases, Bio. org. Med. Chem,.11, 2003, 4785-4789.

[4] KuçukguzelI.,KuçukguzelS.G.,Rollas S.,Otuk-Sanıs G.,Ozdemir O.,BayrakI.,AltugT. and STables J.P., 3-(Arylalkylthio)-4alkyl/aryl-5-(4-aminophenyl)-4H-1,2,4-triazole derivatives and their anticonvulsant activity, Farmaco.59, $2004,893-901$.

[5] Tarafder M.T.,Kasbollah A.,Saravan N., Crouse K.A., Ali A.M., Tin O.K., S-methyldithiocarbazate and its schiff bases: Evaluation of bondings and biological properties, J.Biochem. Mol. Biol. Biophs., 6, 2002, 85-91.

[6] Aletti S.P., Hemminge S. Y., Badiadka N. and Balladka K. S., Synthesis and spectroscopic characterization of some novel Schiff bases of benzylidene derivatives, Der PharmaChemica,6(1), 2014, 1-6.

[7] Hamid L. S., Amjid I., Saeed A. and George W. W., Synthesis and Spectroscopic Studies of New Schiff Bases, Molecules, 11, 2006, 206-211.

[8] Ismaeel Y. M., Duhaa S. and Shaimaa A. S., Synthesis and characterization of some new compounds derivatives from paraaminobenzoic acid, International Journal for Sciences and Technology, 8(3), 2013, 6-11. 
Synthesis, Identification and Evaluation the Biological Activity for Some New Heterocyclic ..

[9] Ezzat H. Z., Synthesis, Characterization and Study Biological activity of some new Sulphadiazine derivatives, International Journal of Chemical and Natural Sciences,2(4), 2014, 109-115.

[10] Suaad M.H. and Lawand H.K, Synthesis and antimicrobial evaluation activity of some new substituted spiro-thiazolidine, Imidazolinone and azetidine derivatives of 5- BromoIsatine, Journal of Zankoisulaimani ,17(1), 2015,49-59.

[11] Rakesh N. M. and Desai K. R., Studies on Synthesis of Some Novel Heterocyclic Azlactone Derivatives and Imidazolinone Derivatives andtheir Antimicrobial Activity, E-Journal of Chemistry,2(1), 2005, 42 -51.

[12] Hilal. M. A., Ibtisam K.J. and Malak N. S., Synthesis and characterization of newheterocyclic compounds with studying its biological activity, Kerbala Journal of Pharmaceutical Sciences,4, 2012, 119-135.

[13] Dhanya S., Ranjitha C., Rama M .,Ksr P., Oxazepine Derivative as an Antitumor Agent and Snail1 Inhibitor against Human Colorectal Adenocarcinoma, International Journal of Innovative Research in Science, Engineering and Technology, 3(8), 2014, $15357-15363$

[14] Uday H. R., Suaad M. H. and Khulood A. S., Corrosion Inhibition Effects of Some New Synthesized N-Aroyl-Nl-Aryl thiourea Derivatives for Carbon Steel in Sulfuric Acid Media, Journal of Al-Nahrain University, 16 (4), 2013, 80-93.

[15] Zainab H., Emad Y., Ahmed A. and Ali A., Synthesis and characterization of Schiff's bases of Sulfamethoxazole, Organic and Medicinal Chemistry Letters, 4(1), 2014,1-4.

[16] Mohammed R. A., Suaad M. H. and Ayad K. K., Synthesis, Evaluation Antimicrobial Activity of Some New N-substituted Naphthalimides Containing Different Heterocyclic Rings, Iraqi Journal of Science, 54(4), 2013, 761-774.

[17] Ruaa M., Synthesis and Characterization of Some Heterocyclic Compounds (Oxazepine, Tetrazole) Derived from Schiff Bases, Journal of Al-Nahrain University, 15 (4), 2012, 60-67.

[18] Anesini C. and Perez C., Screening of plants used in argentic folk medicine for antibacterial activity, J. Ethnrophrmacol,39(2), 1993, 35-47.

[19] Ralph L., Christin K. Hermann T. Morrill D. and Curtin R., Systematic Identification of Organic Compounds ( 8th edition, John and Sons 2004).

[20] Silverstein, R.M. and Bassler, G.C., Spectrometric identification of organic compounds (4th edition, John and Son 1981). 